\title{
HAK DAN KEWAJIBAN Meminum Zinc dan Vitamin C di Masa Pandemi
}

\author{
DEFA NUR IFADA FAUZI
}

IIK STRADA INDONESIA

defaifada2002@gmail.com

\begin{abstract}
Abstrak
Cara untuk menjaga fungsi sistem imun tetap kuat, ada hal mudah yang bisa dilakukan, yaitu memastikan kebutuhan nutrisi tubuh tercukupi. Bagaimana caranya? Mengonsumsi makanan sehat dan bergizi seimbang, terutama yang mengandung vitamin $\mathrm{C}$ dan zinc.Meski banyak sekali nutrisi mikro esensial yang dibutuhkan tubuh dalam meningkatkan imun, kombinasi vitamin $\mathrm{C}$ dan zinc memainkan peran penting. Vitamin $\mathrm{C}$ bekerja dengan cara mendukung fungsi berbagai sel kekebalan dan meningkatkan kemampuan untuk melindungi tubuh dari infeksi.Vitamin $\mathrm{C}$ juga diperlukan untuk regenerasi sel, membantu menjaga sistem imun tetap kuat, dengan cara membersihkan sel-sel lama dan menggantinya dengan yang baru. Vitamin C juga berfungsi sebagai antioksidan kuat untuk melindungi dari kerusakan akibat stres oksidatif.Stres oksidatif adalah stres yang terjadi akibat akumulasi molekul reaktif yang dikenal sebagai radikal bebas. Stres ini memengaruhi sistem kekebalan tubuh dan meningkatkan risiko berbagai penyakit
\end{abstract}

\section{LATAR BELAKANG}

Jakarta - Di masa pandemi, sangat penting untuk menjaga sistem imun tetap kuat. Sistem imun membantu tubuh menangkal zat asing yang dapat menyebabkan penyakit. Namun, jika sudah sakit, peran imunomodulator menjadi sangat penting.Imunomodulator dapat memengaruhi sistem imun tubuh, baik memperkuat atau menekan imun 
agar tidak bereaksi berlebihan. Dengan begitu, sistem imun bisa kembali pulih dan menjalankan fungsinya dengan baik untuk melindungi tubuh.

\section{KASUS / MASALAH}

Alasan Mengapa Vitamin D dapat Mengurangi Risiko Terpapar COVID-19.

Seperti telah dikatakan sebelumnya, vitamin D berperan penting dalam memperkuat imunitas tubuh, bukan hanya untuk menjaga kesehatan tulang. Inilah alasan mengapa setiap orang perlu untuk mencukupi asupan vitamin D. Bila imunitas tubuh kuat, risiko untuk terinfeksi virus Corona pun akan berkurang.

Efektivitas vitamin D dalam menurunkan risiko terkena COVID-19 memang masih perlu dikaji lebih lanjut. Namun, sebuah studi menunjukkan bahwa orang dengan kadar vitamin D yang rendah memiliki peluang 7,2 persen lebih tinggi untuk terinfeksi virus Corona.

Itu artinya risiko Anda untuk jatuh sakit karena COVID-19 akan lebih rendah jika kebutuhan vitamin D harian Anda terpenuhi.

Manfaat vitamin D dalam melawan infeksi virus Corona juga dapat dirasakan oleh pasien COVID-19. Dalam sebuah penelitian, didapati bahwa cukupnya asupan vitamin D mampu mengurangi tingkat keparahan penyakit ini.

Bahkan, risiko pasien COVID-19 untuk mengalami badai sitokin, yaitu komplikasi serius yang berisiko menimbulkan kerusakan organ yang berakibat fatal, dapat berkurang jika ia mendapat asupan vitamin $\mathrm{D}$ yang cukup selama menjalani perawatan.

Cara Memenuhi Kebutuhan Vitamin D

Agar imunitas tubuh kuat dan risiko terinfeksi virus Corona berkurang, Anda harus tetap mematuhi protokol kesehatan dan memenuhi kebutuhan gizi harian tubuh, termasuk vitamin D. Berikut ini adalah beberapa cara untuk mencukupi asupan vitamin D:

\section{Berjemur}

Tubuh akan memproduksi vitamin D secara alami saat berjemur di bawah sinar matahari. Anda dianjurkan untuk berjemur pada pagi hari selama sekitar 15-20 
menit, setidaknya 3 kali dalam seminggu. Waktu berjemur yang ideal untuk pembentukan vitamin D adalah sekitar pukul 08.30 hingga 10.00. Saat berjemur.

Asupan vitamin D juga bisa diperoleh dengan cara mengonsumsi makanan yang mengandung vitamin D. Makanan yang kaya akan vitamin D antara lain adalah ikan salmon, sarden, daging tanpa lemak, hati, kuning telur, jamur, tuna, udang, dan susu serta produk olahannya.

\section{Mengonsumsi suplemen vitamin $D$}

Untuk mencegah kekurangan atau defisiensi vitamin D, Anda dapat melengkapi kedua cara di atas dengan mengonsumsi suplemen vitamin D.

Ada banyak jenis suplemen vitamin D yang beredar di pasaran. Sebaiknya, pilih suplemen vitamin D dengan dosis $1.000 \mathrm{IU}$, karena ini dianggap sebagai dosis yang aman untuk dikonsumsi setiap hari.

Itulah manfaat vitamin D dalam mencegah infeksi virus Corona beserta cara mencukupi asupannya. Tentu saja, Anda juga perlu memenuhi kebutuhan tubuh akan nutrisi lainnya, agar kesehatan Anda lebih terjaga.

\section{PEMBAHASAN}

Meski memiliki manfaat yang sangat baik, vitamin D tidak boleh dikonsumsi secara berlebihan, karena vitamin ini termasuk jenis vitamin larut lemak yang bisa menumpuk di dalam tubuh.Untuk mengetahui apakah asupan vitamin D Anda sudah cukup, kurang, atau justru berlebihan, Anda bisa menjalani pemeriksaan kadar vitamin D dalam tubuh dengan terlebih dahulu berkonsultasi dengan dokter.

Selain mencukupi asupan vitamin D, Anda juga perlu tetap menerapkan protokol kesehatan untuk mencegah COVID-19, yaitu dengan mencuci tangan menggunakan sabun dan air atau hand sanitizer, memakai masker saat berada di luar rumah, menjaga jarak dengan orang lain, menghindari kerumunan, dan menjalani vaksinasi COVID-19. 


\section{KESIMPULAN}

Jika Anda merasakan gejala COVID-19, seperti demam, batuk, sesak napas, badan lelah, nyeri otot, sakit kepala, sakit tenggorokan, hingga anosmia, sebaiknya segera lakukan isolasi mandiri dan secepat mungkin berkonsultasi dengan dokter.

Jika tidak ada bayangan maka itulah puncak sinar UV B. Sinar matahari hanya mampu menghasilkan kadar vitamin D hingga 40\% dengan catatan $80 \%$ dari tubuh harus terkena sinar matahari.

Syarat lama berjemur hanya sampai kulit merah. Presiden Direktur PT Hexapharm Jaya, Mulia Lie juga selalu mencoba menjaga daya tahan tubuh di masa pandemi ini. Dia bilang, rajin konsumsi vitamin D3, vitamin C, minyak ikan dan multivitamin.

Produk tersebut penting sebagai suplemen untuk menambah dari kekurangan vitamin dari makanan yang dikonsumsi. "Vitamin D3 membantu di saat kurang paparan matahari karena banyak beraktivitas di indoor," kata Mulia, Kamis (8/7). Sementara itu, dr Caesar Givani CEO Ceklab menambahkan multvitamin yang dijual di apotek sebab mengandung vitamin C, E, dan lainnya.

"Tapi tidak mengandung vitamin D. Jadi boleh ditambah vitamin D. Vitamin yang dijual di apotek tidak wajib konsumsi setiap hari, hanya saat kondisi drop saja," ujar dia.

\section{DAFTAR PUSTAKA :}

\section{https://www.halodoc.com/artikel/ketahui-pentingnya-zinc-} danvitaminc-di-masa-pandemi 
https://www.alodokter.com/pentingnya-vitamin-d-padasistemimunhadapi-covid-19

https://kesehatan.kontan.co.id/news/jaga-daya-tahan-

tubuhdenganrajin-minum-vitamin-selama-pandemi-covid-19?page=all

Tule, A. R., Siyoto, S., Dwianggimawati, M. S., \& Sodik, M. A. (2018).

The Analysis Factors Affecting Interest In Medication Of Receipt Help Aid Bpjs Participant In Balowerti Public Health Center Kediri City.Journal of Global Research in Public Health,3(1), 68-75.Undang-undang Nomor 24 Tahun 2011 Tentang Badan

Penyelenggaraan Jaminan Sosial (BPJS) Kesehatan,

di download. 25 september 2017 